BNL 50761
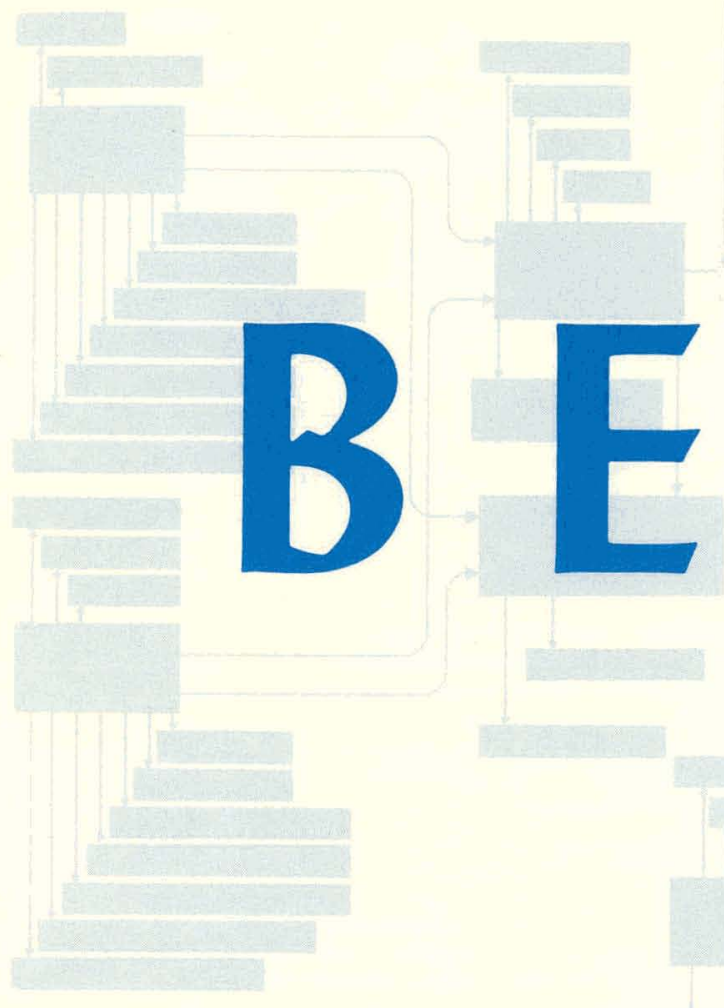
3 31.78

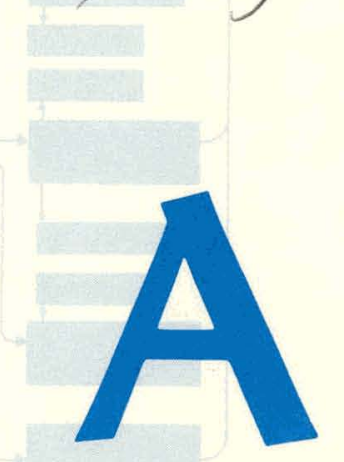

Q. 1965

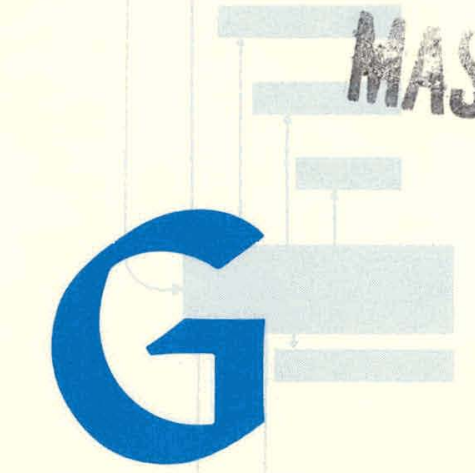

\title{
HAZARDS OF ORGANIC WORKING FLUIDS
}

\author{
Samuel Silberstein
}

\section{AUGUST 1977}

BIOMEDICAL AND ENVIRONMENTAL ASSESSMENT DIVISION

NATIONAL CENTER FOR ANALYSIS OF ENERGY SYSTEMS

\section{BROOKHAVEN NATIONAL LABORATORY}

ASSOCIATED UNIVERSITIES, INC.

UNDER CONTRACT NO. EY-76-C-02-0016 WITH THE

DIVISION OF TECHNOLOGY OVERVIEW/ENVIRONMENT

UNIIED STATES DEPARTMENT OF ENERGY 


\section{DISCLAIMER}

This report was prepared as an account of work sponsored by an agency of the United States Government. Neither the United States Government nor any agency Thereof, nor any of their employees, makes any warranty, express or implied, or assumes any legal liability or responsibility for the accuracy, completeness, or usefulness of any information, apparatus, product, or process disclosed, or represents that its use would not infringe privately owned rights. Reference herein to any specific commercial product, process, or service by trade name, trademark, manufacturer, or otherwise does not necessarily constitute or imply its endorsement, recommendation, or favoring by the United States Government or any agency thereof. The views and opinions of authors expressed herein do not necessarily state or reflect those of the United States Government or any agency thereof. 


\section{DISCLAIMER}

Portions of this document may be illegible in electronic image products. Images are produced from the best available original document. 
BNL 50761

UC-41

(Health and Safety - TID-4500)

\title{
HAZARDS OF ORGANIC WORKING FLUIDS
}

\author{
Samuel Silberstein
}

\section{AUGUST 1977}

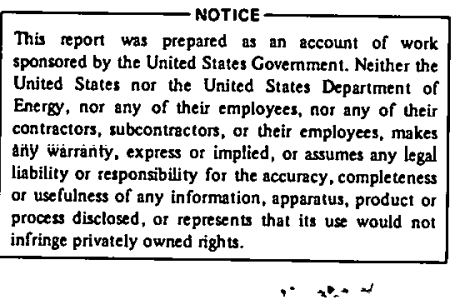

BIOMEDICAL AND ENVIRONMENTAL ASSESSMENT DIVISION NATIONAL CENTER FOR ANALYSIS OF ENERGY SYSTEMS

\author{
BROOKHAVEN NATIONAL LABORATORY \\ ASSOCIATED UNIVERSITIES, INC. \\ UPTON, NEW YORK 11973
}


"The Department of Energy (DOE) is the successor to the Energy Research and Development Administration (ERDA) and all references to ERDA herein shall be deemed to refer to DOE."

\section{NOTICF.}

This report was prepared as an account of work sponsored by the United States Government. Neither the United States nor the United States Department of Energy

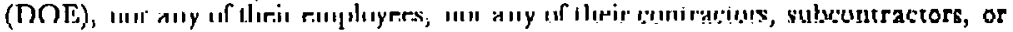
their employees, makes any warranty, express or implied, or assumes any legal liability or responsibility for the accuracy, completeness or usefulness of any information, apparatus, product or process disclosed, or represents that its use would not infringe privately owned rights.

Printed in the United States of America

Available from

National Technical Information Service

U.S. Department of Commerce

5285 Port Royal Road

Springfield, VA 22161

Price: Printed Copy $\$ 4.00$; Microfiche $\$ 3.00$

January 1978

375 copies 
FOREWORD

This review of the hazards of organic working fluids proposed for use in organic Rankine and bi-phase bottoming cycles defines the risks of these fluids apart from the technology. To put these risks into perspective, one must take account of the probabilities of their being released when used in the proposed technologies. Clearly if the risk of release were very small, the hazards would be similarly diminished. The situation here is analogous to the hazards of radiation in the nuclear fuel cycle. The risks are dose-dependent and the degree of risk is directly effected by the amount of radioactivity one permits to be released.

L. D. Hamilton 
We present several brief reviews on working fluids proposed for use in organic Rankine and bi-phase bottoming cycles. These were prepared for the U.S. Energy Research and Development Administration, Assistant Administrator for Environment and Safoty/Oivision of Technology Overview during its preparation of an Environmental Development Plan for the ERDA Division of Conservation Research and Technology. There are several general problems with many organic working fluids: flammability, toxicity, and a tendency to leak through seals. Besides, two of the proposed working fluids are to be used at temperatures above the manufacturer's maximum reconmended temperature, and one is to be used in a way different from its custonary usage.

It may, in some cases, be more profitable to first seek alternative working fluids before committing large amounts of time and money to research projects on unsafe working fluids. 


\section{Introduction}

This report collects brief reviews on working fluids proposed for use in organic Rankine and bi-phase bottoming cycles, prepared for the U.S. Energy. Research and Development Administration Assistant Administrator for Environment and Safety/Division of Technology Overview during its preparation of an Environmental Development Plan for the ERDA Division of Conservation Research and Technology. The porposed working fluids, their projected operating conditions and the manufacturers' recommended operating conditions are presented in Table 1.

We present below some of the general problems of these working fluids and present some recommendations.

At least two of the fluids are to be used at temperatures above those resommended by the manufacturer. Freon 11 is customarily used as a refrigerant. We recommend that any proposed diviation from manufaturers' recommendations or from customary usage should be justified in detail.

Aome of the working fluids are highly flammable and possibly explosive. "It is characteristic of most organic heat transfer fluids to have a tendency to leak through joints and fittings at high temperatures unless these fittings are very tight" 8 exacerbating the risk of fire. Therefore the use of inorganic fluids should be explored.

Some of the fluids are toxic. Leakage may result in worker and possibly general population exposure. Since leakage is a common feature of organic fluids, it should in no way be considered an extraordinary event or an accident. While a fluid like freon 11 is not ordinarily toxic, it may be quite toxic under elevated operating temperatures. Fluorinol 85 is toxic, but the extent of toxicity is undetermined. 
Thus it must be determined whether each fluid is safe under the actual conditions of operation. When it is known that a fluid is unsafe, it may be more profitable to try to find a safe substitute than to embark upon a lengthy and expensive research prpject to determine the exact extent of the fluid's toxicity.

$$
\text { Table } 1
$$

Working Fluids Proposed, for Organic Rankine and Bi-phase Bottoming Cycles

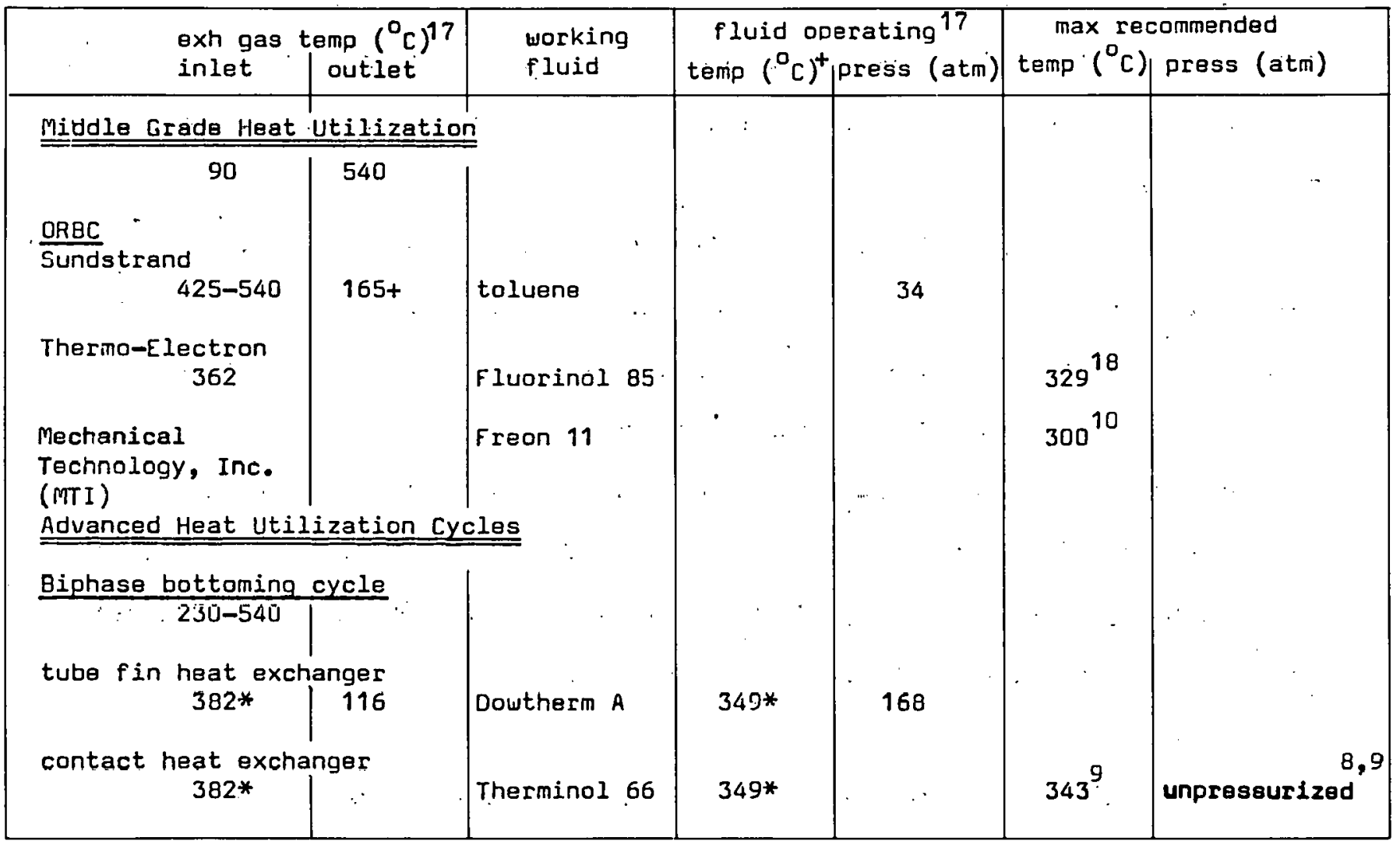

+necessarily less than exhaust gas inlet temperature.

*maximum 


\section{Toluene and benzene}

The Sundstrand organic Rankine bottoming cycle (ORBC) is designed for toluene as working fluid for $425^{\circ} \mathrm{C}$ or above. Is it advisable. to use a highly flammable liquid at these elevated temperatures? If air contains 12,000 ppm of toluene, it can be ignited. What safeguards will prevent this concentration from being approached?

while reagent grade toluene is relatively pure, industrial grade toluene can contain as much as $25 \%$ benzene, ${ }^{1,2}$ resulting in a vapor that could be $50 \%$ benzene. 2 Tolvene is töxic; benzene even worse.

Heat catalyzes the following reactions:

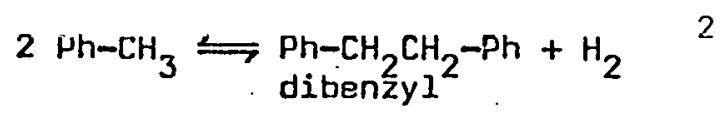

$$
\begin{aligned}
& 2 \text { benzene } \leftrightharpoons \underset{\text { diphenyl }}{\text { Ph-ph }}+\mathrm{H}_{2} \quad 3
\end{aligned}
$$

Are these reactions significant in the Sundstrand URBC producing highly explosive $\mathrm{H}_{2}$ ? If so, what are the safety measures?

There are two dangers associated with exposure to working fluids: chronic low-lovel exposure to workers and the general population due to leakage, and acute high level exposure in the vicinity of the unit due to catastrophic relaese of fluid. 
Table 2

Inhalation of Toluene and Benzene (Humans Unless, Otherwise Stated). 2,3

Low Dose. 0.5 -0.9 ppm benzens

0.4 ppri toluene

50-100 ppr toluens

$200 \mathrm{ppm}$ toluene

benzene

- bonzene

25 ppm benzene

100 ppm benzene

- benzene

200 ppm toluene

4לU-לUU p̄p̃ñ Benzene rats

133 or $13.3 \mathrm{ppm}$ toluene rats, rabbits

High Dose. 20,000 ppm benzene

4000 ppm toluene

rats

Suggestive study. Rats injected. $1 \mathrm{mg} / \mathrm{kg} /$ diay toluene $0.8 \mathrm{gm} / \mathrm{kg} /$ day toluene acute enhanced brain electropotential

chronic drowsiness and mile headache no aftereffects

chronic insomnia

headache

dizziness

fatigue

nausea

chronic stable and unstable chromosome aberration

chronic anemia

thrombocytopenia

thrombocytopathy

leukopenia

low hemoglobin conc

increased cell size

eosinophil count elevation

chronic leukopenia

chronic leukemia

chronic unstable chromosome aberrations; not statistically significant.

chirulic irluiease in eytochrome $\Gamma 450$ and aminopyrine demnthylaro activity.

chronic decrease in cholinesterase

leukocytosis

Liliculocytosis at higher cono

immunological inhibition at both levels

acute death

(5 min)

4 hours death

chronic chronic

bone marrow chromosome damage

stimulation of neutropossis

chromosome breaks

metaphase aberrations 
Human Exposure to Toluene and Benzene. (Refer to Table 2)

Exposure to about $0.4-0.5 \mathrm{ppm}^{2,3}(0.27 \mathrm{ppm}$ for toluene in Ref. I) of either toluene or benzene produces an enhanced brain electropotential of unknown significance. The OSHA Occupation Standard for toluene is $100 \mathrm{ppm}$ time weighted average (TWA) for 8 hours/day and a 40 hour workweek with a ceiling of 200 ppm. $^{4}$ The central nervous system effects of toluene are seen at concentrations even below this standard. Low-level chronic exposure to benzene results in similar central nervous system symptoms. ${ }^{5,6}$ In addition, there is also damage to the hematopoietic system. These effects occur at a previous ceiling limit of 25 ppm of the Occupational Safety and Health Administration (OSHA). The OSHA ceiling limit has recently been lowered to $1 \mathrm{ppm}$ from $10 \mathrm{ppm}$ time weighted average for an 8 hour workday; the new ceiling limit is $5 \mathrm{ppm}$ for 15 minutes. 16 These revisions were made because benzene is associated with increased risk of leukemia. $3,4,7,16$ Does toluene cause chromosome aberrations in the bone marrow? The experiment that seems to suggest that it does was done by injecting rats with toluene, while the more likely route of introduction of toluene for humans is inhalation. Does toluene also affect the hematopoeitic system? Benzene seems to effect liver function (by raising cytochrome 450 and aminopyrene demethylase activity). Does toluene lessen the ability of liver to detoxify:blood?

At high acute concentrations, benzene and toluene cause narcosis because of their affinity for nerve-cell lipids. This can cause death either directly or by rendering an exposed worker incapable of leaving the site of leakage of working fluid after which he may die if the fluid ignites.

If it is determined that toluene can safely be used in this application, a grade uncontaminated with benzene should be used. "In 1971, a conference of the International Labour office (ILO) adopted a Convention and Recommendation concerning protection against hazards of poisoning arising from benzene which 
specified an environmental concentration in the workplace not to exceed a ceiling value of $25 \mathrm{ppm}(80 \mathrm{mg} / \mathrm{cu} \mathrm{m})$ for benzene or products containing benzene at more than $1 \%$ by volume. Restrictions on the use of benzene specified that whenever harmless or less harmful substitute products were available, substitution was mandatory. 17,19

Dther environmental effects.

The aquatic toxicity ratings are:

Benzene $\quad \mathrm{TL}_{\mathrm{m}} 96=100-10 \mathrm{ppm}$ (slightly toxic)*

Tolvene

"

Both benzene and toluene are acutely toxic to aquatic vertebrates. Poisoning can occur at $5-10 \mathrm{ppm}$ and death at $20 \mathrm{ppm} .2,3$

Both have injurious effects on photosynthesis at concentrations below $10 \mathrm{ppm}^{2,3}$

Metabolism of tolvene and benzene in humans, $1,2,3,7$

The solubilities in water at room temperature are:

$\begin{array}{lll}\text { benzene } & \text { about } 0.8 \mathrm{gm} / 1 & 3 \\ \text { toluene } & \text { about } 0.5 \mathrm{gm} / 1 & 2\end{array}$

Since benzene and toluene have limited solubilities in blood, equilibration with the vapor occurs rapidly. However, benzene is more soluble than toluene, and is, therefore, more readily absorbed from the air. (28-50\% of inhaled benzene is retained by the blood. ${ }^{3}$ ) Both benzene and toluene are lipophilic and accumulate in tissues rich in lipids like the bone marrow, adrenal glands, fatty tissue and brain. The affinity of toluene for tissues is three times as great as its affinity for blood. ${ }^{2}$

Faccorcing to rating scheme in ref. 4 , where $\mathrm{IL}_{m} g 6$ is also defined. 
Half of the absorbed benzene is ultimately eliminated unchanged by the lungs, with only $0.1-0.2 \%$ excreted unchanged by the kidneys. The remainder is oxided to phenols and diphenols and excreted as such or conjugated with $\mathrm{SO}_{4}$ ions in the liver and excreted as esters of glucuronic and sulfuric acid in 48 hours. Only $20 \%$ of the absorbed toluene is exhaled by the lungs. The remaining $80 \%$ is oxidized to benzoic acid, complexed with glycine to hippuric acid and excreted. (Sixty-eight percent of the absorbed tolvene is excreted as such within 18 hours in one study.)

$$
\begin{array}{ll}
\text { Pr:- }-\mathrm{CO}_{2} \mathrm{H} & +\mathrm{NH}_{2} \mathrm{CH}_{2} \mathrm{CO}_{2} \mathrm{H} \longrightarrow \\
\begin{array}{l}
\text { benzoic gh- } \\
\text { acid }
\end{array} & \text { hipcins }
\end{array}
$$

This metabolic pathway may account in part for the greater toxicity of benzene over toluene. Toluene may slow down the metabolism of benzene, thus making a fixed amount of benzene more toxic:? 
II: Therminol 66

Therminol 66, manufactured by Monsanto Industrial Chemicals Co., St. Louis, Missouri, is proposed as the working fluid for testing the direct contact heat exchanger of the bi-phase bottoming cycle turbine system. The Therminols are a class of heat transfar fluids of varying operating temperature ranges; for example, Therminol 66 is designed to be operated between $-9^{\circ} \mathrm{C}$ and $343^{\circ} \mathrm{C} .^{9}$ Therminols are hydrogenated ter-phenyls whose double bond content is proprietary information.

Therminols are quite flammable. The following information is given by the manufacturer: "Heat transfor.fluids are intended only for indirect heating purposes." 8 "In heat transfer installations, the fluid is used in a closed, non-pressurized system free from leaks..." "It is characteristic of most organic heat transfer fluids (including Therminol) to have a tendency to leak through joints and fittings at high temperatures unless these fittings are very tight.... Control of piping leaks is expecially important, since fluid-soaked insulation poses a more serious hazard than the leaking fluid itself.... Organic heat transfer fluids such as Therminol exhibit a slow oxidation with the air trapped inside the voids of the insulating material when the system temperatures reach about $260^{\circ} \mathrm{C}$.... This temperature build-up can result in ignition of the fluid when the space between the piping and the saturated insulation is exposed to air." 8 "To minimize fluid oxidation, systems utilizing Therminol 66 fluid should be blanketed with an inert atmosphere." 9

In the bi-phase cycle system, Therminol 66 is to be used not in a closed, tightly sealed system blanketed with inert gas, but in direct contact with exhaust gases. According to Resource Planning Associates, Inc. (RPA), these gases, having a maximum temperature of $382^{\circ} \mathrm{C}$ will heat up the working fluid to a maximum temperature of $349^{\circ} \mathrm{C}$. 
There are some disturbing features of this intended use of Therminol 66:

1. It is to be used at a temperature beyond its useful operating range. This problem could easily be solved by substituting another fluid from the Therminol series since there are Therminols that can be used up to $427^{\circ} \mathrm{C}$, but there are more serious problems.

2. Therminol 66 will be used in an open system, exposed to hot gases. Several questions are raised: Is enough $0_{2}$ present in these gases to ignite or oxidize the working fluid? Can NO or $\mathrm{NO}_{2}$ substitute for $\mathrm{O}_{2}$ ? Will the working fluid be exposed to burning particulate matter that can ignite it?

3. It is not clear from the description in the RPA working paper ${ }^{17}$ whether the working fluid spends any of its time in a pressurized system. As we have seen, the Therminols are designed far use in non-pressurized systems. (Further: Therminol 66 fluid is designed for use in non-pressurized indirect heating systems." ${ }^{9}$ ).

4. If Therminols contain any double bonds or aromatic rings, they can probably react with some of the components of the exhaust gases ( $\mathrm{CO}, \mathrm{NH}_{2}, \mathrm{NO}, \mathrm{NO}_{2}$, $\mathrm{SO}_{2}, \mathrm{SO}_{3}$, and water), especially in the prevailing acidic conditions of the exhaust gas. Reactions may produce toxic substances and will render the Therminols unfit for their intended use.

5. Therminols are ring compounds that may contain an aromatic ring. Compounds of this nature may be carclnagenlc.

It appears that Therminol 66 was a poor choice for the application described above. A more suitable fluid, preferably an inorganic one, should be found. 
III. Freon 1.1

Mechanical Technology, Inc. (MTI) proposes to use Freon 11 as the working fluid for its ORBC. RPA states that the system is in early stages of planning so that no component specifications are available. The exhaust gas termpereture is not specified; it is somewhere between $90^{\circ} \mathrm{C}$ and $540^{\circ} \mathrm{C}$. (It is not clear how the selection of a working fluid could be made without detailed knowledge of operating conditions like temperature and pressure.)

Freon 11 is a fluorocarbon refrigerant and can undergo three types of reactions that are typical of these compounds and are of special concern for the proposed application:

1. Pyrolysis. 10

The following two reactions take place:

$$
\text { (1) } \underset{\text { Freon }}{2 \mathrm{CCI}_{3} \mathrm{~F}} \rightleftharpoons \mathrm{Cl}_{2}+\underset{\mathrm{Frean}_{11} \mathrm{CCl}_{2} \mathrm{FCCl} F}{\rightleftharpoons}
$$

occurs first but only to a limited extent. Disproportionation:

$$
\text { (2) } 2 \mathrm{CCl}_{3} \mathrm{~F} \rightarrow \mathrm{CCl}_{2} \mathrm{~F}_{2}+\mathrm{CCl}_{4} \cdot \mathrm{FreOn}^{2} 12 \text { carbon totraohlorido }
$$

Further disproportionation of Freon 12 yields freon 13 ( $\mathrm{CClF}_{3}$ ) and eventually $\mathrm{CCl}_{4} \cdot \mathrm{CCl}_{4}$ decomposes to carbonaceous solids and chlorine gas.

Dupont, the manufacturer, recommends that a refrigerant not be used above that, temperature at which the rate of decomposition (pyrolysis) exceeds $1 \% /$ year. For freon 11 this temperature is $\sim 300^{\circ} \mathrm{C}$. The stability of fluorocarbon. refrigerants followe the ordor: Freon $22<11<114<115<12<13.10$

2. Reaction with lubricating oil. 10

Fluorocarbon refrigerants react with oils to form unstaurated oils, which can polymerize to form varnish, sludge and coke deposits that foul the system. Aluminum 
seems to catalyze this reaction. The stability towards oil follows the order:

$$
\text { Freon } 11<12<114<115<22 \text {. }
$$

3. Reaction with metals. it

Fluorocarbon refrigerants react with metals to form metal chlorides, fluorides and carbon. 11 when left in a sealed tube for two years at $150^{\circ} \mathrm{C}$, less than $1 \%$ of the freon 11 decomposes, even in the presence of aluminum, inconel alloy or iron. SS 316 alloy increases the extent of decomposition to 5.3\%, and copper to 60\%. Air increases the decomposition of the refrigerant. At $260^{\circ} \mathrm{C}$ and 41 atmospheres of pressure for 25 hours, ss 316 alloy decomposes freon $117.1 \%$ and inconel alloy 10\%. At $370^{\circ} \mathrm{C}$ and the same pressure, both alloys decompose Freon $1119 \%$ in 25 hours. $^{12}$ Parmelee's data ${ }^{12}$ seem contradictory, expecially for copper, aluminum and oil. Tests with the actual heat exchanger tubing should be conducted under operating conditions.

The stability of fluorocarbon refrigerants towards metals follows the order: ${ }^{12}$ Freon $11<113 \times 1381<12,114<22<115<c 318$.

MTI should justify its choice of freon 11 as the working fluid when it has the lowest overall stability towards reactions that can occur in the proposed application (assuming that a fluorocarbon refrigerant should be used at all).

\section{Carcinogenicity}

Freon 11 contains the impurities freon $12\left(\mathrm{CCI}_{2} F_{1}\right)$ and carbon tetrachloride $\left(\mathrm{CCl}_{4}\right) .^{12}$ If heated high enough, frean 11 will break down to freon $112\left(\mathrm{CFCl}_{2} \mathrm{CFCl}_{2}\right)$. and additional freon 12. Freon 12 decomposes to freon 114 ( $\mathrm{CClF}_{2} \mathrm{CClF}_{2}$ ) and Freon $13\left(\mathrm{CClF}_{3}\right)$, which yields freon $116\left(\mathrm{CF}_{3} \mathrm{CF}_{3}\right)$ and freon 14 ( $\mathrm{CF}_{4}$, carbon 
tetrafluoride). Freor 11,12 , and 13 all iltimately yield $\mathrm{CCl}_{4}{ }^{\circ} \mathrm{CCl}_{4}{ }^{10}$, freon 112 and Freon 113 (as well as the closely related chloroform ( $\left.\mathrm{CHCl}_{3}\right)$ ) are known to be carcinogenic alkylating agents. ${ }^{13}$ The remainder of the above compounds, especially freon 11, should be tested because of their obvious chemical similarity to these known carcinogens. The amount of contamination of the atmosphere should be tested under normal and extraordinary operating conditions to determine whether there is any detectable exposure to carcinogens. It should be noted that by selecting one of the least stable fluorocarbon refrigerants as the working fluid, the likelihood of obtaining carcinogenic decomposition products is maximized (assuming that the working fluid itself is not carcinogenic).

\section{Other potential problems}

Since the boiling point of freon 11 is $24^{\circ} \mathrm{C}$, it is a liquid at ambient temperatures a good part of the year and can, therefore, contaminate water through leakage. (The solubility is $44 \mathrm{ppm}$ at $4.4^{\circ} \mathrm{C}$ and $168 \mathrm{ppm}$ at $\left.38^{\circ} \mathrm{C}.\right)^{14}$ It is possible that if there is a leak in the system and the hot working fluid comes into contact with air or exhaust gas, poisonous gases like phosgene $\left(\operatorname{COCl}_{2}\right)$, fluorophosqene $\left(\operatorname{COF}_{2}\right), \operatorname{COClF}, \mathrm{HF}, \mathrm{HCl}$, as well as $\mathrm{F}_{2}$ and $\mathrm{Cl}_{2}$ might be released.

Phosgene has been used as war gas. It is an "insidious poison as it is not irritating immediately, even when fatal concentrations are inhaled. May cause severe pulmonary edema. (may be quickly fatal) or pneumonia.... Vapors strongly irritating to eyes."15 The Merck index then warns that specially soaked paper must always be present as an indicator whenever generation of phosgene is possible or suspected.

Fluorophosgene is "a ctrong irritant to skin, eyps, murnus membranes, respiratory tract." 15 
Finally, it should be specified how used working fluid will be disposed of. "... we can appreciably enhance the destructivity of the stratosphere for ozone by the infiltration of a relatively small amount of $F-11$ or $F-12 . " 16$ (F $=F$ reon.) The result of ozone destruction can be higher incidences of skin cancers, ${ }^{16}$ which will be equally severe whether the fluorocarbon refrigerants enter the atmosphere through "accidental" leakage or through "intentional" disposal. 
IV. Fluorinol 85

Fluorinol $85\left(\mathrm{~F}_{3} \mathrm{CCH}_{2} \mathrm{OH}\right.$, trifluoroethanol) may be capable of breaking

down to fluorophosgene at high temperatures. (see section on Freon 11).

The information below was supplied by the manufacturer, Halocarbon

Products Corp. 18

\section{TOXICITY}

Preliminary toxicity data for trifluorcethanol are: acutc oral $\mathrm{LD}_{50}: 240 \mathrm{mg} . / \mathrm{kg}$.; acute dermal $\mathrm{LD}_{50}$ : $1680 \mathrm{mg} . / \mathrm{kg}$.; and acute inhalation $\mathrm{L}(\mathrm{ct})_{50}: 4600 \mathrm{ppm}$. hrs. According to standards established by the Manufacturing Chemists Association (a) the acute ural $\mathrm{LD}_{\overline{50}}$ falls in the catcgory of a toxio eubstance. Therefore, if ingested, efforts should be made to remove it from the stomach. A serics of subhypnotic doses of ethanol is antidotal for trifluoroethanol toxicity in animals (b) and probably in humans.

Trifluoroethanol is not classified as toxic via the dermal or inhalition pathways (a). Nor is it a primary skin irritant, but contact with the skin should be avoided to prevent dermal absorption. Spills are readily washed off with water. Inhalation of the vapors should be avoided by working in a well ventilated area.

Animal studies have shown that trifluoroethanol causes severe eye damage sinilar to many chemicals (such as isopropyl alcohol and toluene). Immediate washing of the eye with water should be used following any splashes.

Subchronic inhalation exposure ( 6 hours per day, 5 days a week for 4 weeks) of male rats to $150 \mathrm{ppm}$ of trifluoroethanol caused testicular depression (hypospermatogenesis and atrophy of the seminiferous tubules) leading to infertility lasting for at least 5 weeks ofter the exposure. Similar exposure to $10 \mathrm{ppm}$ had no effect and the effect was transient after exposure to $50 \mathrm{ppm}$. While the significance of these observations for human safety is unknown at the present time, it is recommended that continuous exposure to atmospheric concentrations greater than $10 \mathrm{ppm}$ be avoided.

(a) "Guide to Precautionary Labeling of Hazardous Chemicals", Seventh Edition, 1970, Manufacturing Chemists Association, 1825 Connecticut Ave., N.W., Washington, D.C. 20009.

(b) D. A. Blake, H. F. Cascorbi, R. S. Rozman and F. J. Meyer, Toxicology and Applied Yharmacology 15, 83 (1909). 
References

1. Criteria for a Recommended Standard...occupational Exposure to Toluene (1973). NIOSH, Washington, D.C.

2. P. Walker, Air Pollution Assessment of Toluene (May-1976). MTR-7215, Mitre Corp., Mclean, Va.

3. F. Walker, Air Pollution Assessment of Benzene (April 1976). MTR-7188, Mitre Corp., Mclean, Va.

4. Registry of Toxic Effects of Chemical Substances (1976). NIOSH, Washington, D.C.

5. N. Irving Sax, Dangerous Properties of Industrial Materials, 4 th ed. (1975). Van Nostrand Reinhold Co., New York, N.Y.

6. Gleason et al., Clinical Toxicology of Commercial Products, 3rd Ed. (1969). The Williams \& Wilkins Co., Baltimore, Md.

7. Criteria for a Recommended Standard... Occupational Exposure to Benzene (1974). NIOSH, Washington, D.C.

8. Therminol heat transfer fluids, Monsanto Industrial Chernicals Co., St. Louis, Mo.

9. Therminol 66, Monsanto, October 1976 (insert in Ref. 8).

10. Hans J. Borchardt, New Findings Shed Light on Reactions of Fluorocarbon Regrigerants (1975). Freon Product Information RT-58, E. I. Dupont de Nemours \& $\mathrm{Co}$. (Inc.), wilmington, Del.

11. Dr. Downing of Dupont, Telephone conversation.

12. H. M. Parmelee, Sealed-Tube Stability Tests on Refrigeration Materials (1976). Freon Product Information RT-42, Dupont.

13. P. D. Lawley in Chemical Carcinogens, C. E. Searle, ed. (1976). 83-244 (see table on P. 158-9). American Chemical Society, washington, D.C.

14. Thermodynamic Properties of Freon 11 Refrigerant (1976). Dupont publication $T-11$.

15. The Merck Index, 9th ed., M. Windholz, ed. (1976). Merck, Inc., Rahway, N.J.

16. Benzene Health Hazard. Brookhaven National Laboratory Safety \& Environmental Protootion Division Information Bulletin, Issue nu. 2, Sept., 1977.

17. Draft Technology Characterization of CONRT Projooto for the FY 1970 EDP, July 13, 1977. Resource Planning Assuciates, Inc., Washington, D.C.

18. Fluorinols, October 28, 1975. Halocarbon Products Corp., Hackensack, N.J.

19. 56th session, International Labor Conference, Geneva, June, 1971. 


\section{Acknowledgments}

I am grateful to L. D. Hamilton, M. E. Baser, J. P. Brainard, E. Kaplan, P. D. Moskowitz, J. Nagy, M. D. Rowe and W. A. Sevian for their helpful discussion and review of this paper. 